January 1991

\title{
Bringing Back the Mind
}

\author{
Edward Kim, M.D. \\ Thomas Jefferson University
}

Follow this and additional works at: https://jdc.jefferson.edu/jeffjpsychiatry

Part of the Psychiatry Commons

Let us know how access to this document benefits you

\section{Recommended Citation}

Kim, M.D., Edward (1991) "Bringing Back the Mind," Jefferson Journal of Psychiatry. Vol. 9 : Iss. 1 , Article 14.

DOI: https://doi.org/10.29046/JJP.009.1.013

Available at: https://jdc.jefferson.edu/jeffjpsychiatry/vol9/iss1/14

This Article is brought to you for free and open access by the Jefferson Digital Commons. The Jefferson Digital Commons is a service of Thomas Jefferson University's Center for Teaching and Learning (CTL). The Commons is a showcase for Jefferson books and journals, peer-reviewed scholarly publications, unique historical collections from the University archives, and teaching tools. The Jefferson Digital Commons allows researchers and interested readers anywhere in the world to learn about and keep up to date with Jefferson scholarship. This article has been accepted for inclusion in Jefferson Journal of Psychiatry by an authorized administrator of the Jefferson Digital Commons. For more information, please contact: JeffersonDigitalCommons@jefferson.edu. 


\title{
Bringing Back the Mind
}

\author{
PSYCHODYNAMIC PSYCHIATRY: THEORY AND PRACTICE \\ John Frosch, M.D. \\ 1990, International Universities Press \\ Vol I, 359pp, $\$ 50.00$ \\ Vol II, 505pp, $\$ 60.00$
}

\section{Edward Kim, M.D.}

American psychiatry is currently experiencing a renewed interest in applications of psychoanalytic theory to clinical practice. There may be several reasons for this. As the "Decade of the Brain" produces more powerful and sophisticated biological interventions in psychiatry, it will inevitably produce more potential disappointments. Few psychiatric residents I've met have expressed an aversion to learning about psychodynamic principles; in fact, most seem to feel that this is an important part of residency training. It's therefore no surprise that in 1990, two major works on psychodynamic psychiatry have been published. Glen Gabbard's Psychodynamic Psychiatry in Clinical Practice (1) was reviewed in the last issue of the Journal. Published by American Psychiatric Press, it was well-received as a concise if at times limited overview of dynamic principles as applied directly to DSM-III-R diagnoses. In this sense it has an immediate utility for residents seeking to grasp some of the dynamics which are lost in an inherently descriptive classification system. John Frosch's Psychodynamic Psychiatry: Theory and Practice uses a different approach. Dr. Frosch stays firmly within a psychoanalytic nosology as he discusses classes of mental disorders which are grouped according to dynamic rather than descriptive features. This approach has the benefit of bringing the reader into a richer understanding of psychoanalytic theory at the expense of the familiarity and user-friendliness of Gabbard's book. This is not to say that Frosch loses the reader in his discussion. Although dense and complex in places, at no point does the book seem irrelevant or overly abstract. Frosch has a talent for progressively developing his points, leading the reader into more sophisticated and multilayered discussions of the various syndromes. The breadth and depth of his fifty-plus years of experience are apparent as he reviews the contributions of numerous authors from a variety of analytic schools-Freudian, Kleinian, self psychological. I was at times relieved when he referred to some of his own work in order to help me synthesize all of these viewpoints. One might fault Dr. Frosch for presenting too exhaustive a review of the relevant analytic literature. However, the complexity and controversy which at times present difficulties make this a book which will not be quickly outgrown. The cases presented are at times entertaining, personal, and very educational. They demon- 
strate the need for sound clinical judgment rather than formulaic axioms when dealing with the ambiguous subtleties of human experience.

The book comes in two substantial volumes, with references and index at the end of volume two. Volume one is largely devoted to a comprehensive overview of psychoanalytic theory. Frosch discusses the problems in developing a system for rationally classifying mental illnesses. He then presents the historical development of various psychoanalytic paradigms-topographical, libido, dual instinct, structural-in order to address this task. This is followed by a discussion of human psychic development through the entire life cycle, giving much-needed attention to the effects and meaning of becoming a parent, reaching mid-life, and aging. A third chapter addresses metapsychological concepts such as the sense of self, object relations, defense mechanisms, and character versus symptom neurosis. Over two hundred pages are devoted to this introductory section. In many ways it could stand on its own as a primer on psychoanalytic theory for the general psychiatrist. The first volume is completed with chapters on disorders of childhood and adolescence, and neuroses.

Volume two continues with chapters on affective disorders, psychoses, psychosomatic medicine, impulse and psychosexual disorders, and character disorders. These groupings are something of a middle ground between analytic and descriptive nosology. A major difficulty in the discussion of clinical syndromes is Dr. Frosch's failure to consistently or systematically refer to the DSM-III-R disorders which would correspond to the entities he addresses. I felt the need to oscillate between the text and my residency-trained DSM-III-R frame of reference. My conclusion was that this extra effort was a reasonable price to pay for exposure to the deeper structure of psychodynamic psychiatry; facile translations of analytic to descriptive frames were not possible, however desirable.

A particular strength of the book is the chapter on psychoses. Our current understanding of psychotic disorders focuses on neurobiological models without respect for the content and form of the symptoms. Having written an excellent book on dynamic aspects of psychosis (2), Dr. Frosch brilliantly describes how psychotic patients can craft a world of their own in response to the neurochemical derangements in their brains. This adds a very human quality to the understanding and treatment of patients suffering from psychoses. Dr. Frosch's expertise and knowledge become especially evident as he refers to contributions from ego psychology, object relations theory, and libido theory in his discussion of the inner world of the psychotic patient. Compromising between the conflict and deficit models of psychosis, Dr. Frosch proposes that patients may use their neurobiological vulnerability to psychosis as a defense against a primitive anxiety, the fear of total dissolution of the self. $\mathrm{He}$ continues by describing the role of positive symptoms such as hallucinations and delusions as abortive attempts by patients to reestablish contact with the object world following a prodromal withdrawal from reality.

The chapter on character disorders discusses syndromes which have been well-described in the analytic literature. It fills in many of the deficiencies of the DSM-III-R nosology of personality disorders, focusing more on intrapsychic and 
interpersonal than behavioral factors. Again, this approach is much more useful in understanding the complexities of character-disordered patients who present for treatment other than acute intervention.

Another gem in the book is the chapter on psychodynamic psychotherapy. The various dynamic conceptions of supportive versus expressive psychotherapies are presented in a very clear fashion. Moreover, Dr. Frosch addresses the controversy surrounding the distinction between psychodynamic psychotherapy and psychoanalysis. He seems to consider the differences to be quantitative rather than qualitative, and describes the more limited goals of psychotherapy. The setting of treatment goals is something residents are accustomed to during the inpatient years; treatment goals can be more elusive and difficult to conceptualize as training focuses on outpatient psychotherapy. Frosch neither mandates concrete, quantifiable objectives, nor does he imply that complete exploration of unconscious and defensive processes is the best goal, even with insight-oriented cases. Instead, he argues for individually determined objectives based on the resources, motives, and circumstances of the patient. This presents a treatment stance which is neither rigid nor superficial.

Psychodynamic Psychiatry: Theory and Practice is not without its share of flaws. The copy editing is uneven, with some bizarre grammatical errors and occasionally very awkward style. There is a redundancy which in some ways is unavoidable, as the same theoretical material is presented in several different sections where it is clinically relevant. In other cases it is avoidable; childhood psychosexual development is outlined in the initial theoretical chapters, then resummarized at the beginning of nearly every section in which addresses deviations from this norm. Another problem is the length and price. At nearly 800 pages and $\$ 110.00$, this is quite an investment. Nevertheless, I found the book to be both captivating and challenging. It lacks the smoothness and organization of Glen Gabbard's book and thus would not make an easily digestible textbook for residents. Prior reading and supervision in dynamic principles are necessary before this material is accessible. But for residents desiring a broad and comprehensive reference to psychodynamic theory, this book will prove valuable for years to come.

\section{REFERENCES}

1. Gabbard, GO: Psychodynamic Psychiatry in Clinical Practice. Washington, DC, American Psychiatric Press, 1990

2. Frosch, J: The Psychotic Process. New York, International Universities Press, 1983 